\title{
Gynecological Examination
}

National Cancer Institute

\section{Source}

National Cancer Institute. Gynecological Examination. NCI Thesaurus. Code C137854.

Physical examination pertaining to the female reproductive system. 